\title{
PENINGKATAN KETERAMPILAN PEGAWAI KECAMATAN GUNUNGTANJUNG KABUPATEN TASIKMALAYA MELALUI PELATIHAN PENULISAN SURAT DINAS
}

\author{
Rina Agustini \\ Program Studi Pendidikan Bahasa dan Sastra Indonesia \\ Fakultas Keguruan dan Ilmu Pendidikan, Universitas Galuh, Indonesia \\ E-mail : rinaagustini21@yahoo.com
}

\begin{abstract}
The sub-district office is a government institution that uses letter media in delivering information or activities carried out to support government programs. Writing official letters is one of the activities in administration that can help smooth the activities of the administration. Therefore, writing official letters is very important to be understood by all sub-district office employees to support the administrative work process. The purpose of this service activity is to find out the understanding of writing official letters of the Gunungtanjung District Office of Tasikmalaya District and to find out an increase in understanding of writing official letters of the Gunungtanjung District Office in Tasikmalaya District. The implementation of Community Service activities is packaged using a workshop approach. The activity was carried out using the method of lecture, discussion and practice. The achievement of the training activities was the increasingly motivated sub-district office staff to improve their competence and professionalism in writing official letters. The quality of official letters that have been produced by employees of the Gunungtanjung District Office in Tasikmalaya Regency has also increased as explained below. 20 official letters with very good categories, 7 official letters with good categories, and 3 official letters classified as sufficient (score <70). The training activities benefited the participants and were expected to improve the quality of services in the Gunungtanjung District Office in Tasikmalaya Regency. Keywords: official letter, sub-district employee.
\end{abstract}

\begin{abstract}
Abstrak
Kantor kecamatan merupakan lembaga pemerintah yang menggunakan media surat dalam menyampaikan informasi atau kegiatan-kegiatan yang dilaksanakan guna mendukung program pemerintah. Penulisan surat dinas merupakan salah satu kegiatan dalam administrasi yang dapat membantu kelancaran aktivitas bidang administrasi. Oleh karena itu, penulisan surat dinas sangat penting dipahami oleh semua pegawai kantor kecamatan untuk mendukung proses kerja administrasi. Adapun tujuan dilaksanakannya kegiatan pengabdian ini yaitu untuk mengetahui pemahaman penulisan surat dinas pegawai Kantor Kecamatan Gunungtanjung Kabupaten Tasikmalaya dan untuk mengetahui peningkatan pemahaman penulisan surat dinas pegawai Kantor Kecamatan Gunungtanjung Kabupaten Tasikmalaya. Pelaksanaan kegiatan Pengabdian Pada Masyarakat ini dikemas dengan menggunakan pendekatan workshop. Kegiatan dilakukan menggunakan metode ceramah, diskusi dan latihan. Pencapaian dari kegiatan pelatihan ialah semakin termotivasinya para pegawai kantor kecamatan untuk meningkatkan kompetensi dan profesionalitasnya dalam penulisan surat dinas. Kualitas surat dinas yang telah dihasilkan oleh para pegawai Kantor Kecamatan Gunungtanjung Kabupaten Tasikmalaya juga mengalami peningkatan sebagaimana uraian berikut. 20 surat dinas dengan kategori sangat baik, 7 surat dinas dengan kategori baik, dan 3 surat dinas tergolong katerori cukup (skor $<70$ ). Kegiatan pelatihan dirasakan manfaatnya oleh para peserta dan diharapkan dapat meningkatkan kualitas pelayanan di Kantor Kecamatan Gunungtanjung Kabupaten Tasikmalaya.
\end{abstract}

Kata kunci: surat dinas, pegawai kecamatan.

\section{PENDAHULUAN}

Pelaksanaan kegiatan administrasi kantor diarahkan kepada pencapaian tujuan lembaga tersebut. Salah satu faktor pendukung keberhasilan pencapaian tujuan lembaga secara efektif dan efisien adalah kelancaran dan ketertiban dalam bidang administrasi yang akan senantiasa mendukung efisiensi dan efektivitas kerja. Setiap kegiatan lembaga atau organisasi selalu membutuhkan surat sebagai alat komunikasi untuk mencapai koordinasi kerja yang harmonis. Di era globalisasi ini memang teknologi 
sudah berkembang dengan sangat pesat. Berbagai alat komunikasi canggih telah berhasil diciptakan. Akan tetapi, pada kenyataanya kedudukan surat sebagai sarana komunikasi belum sepenuhnya tergantikan. Apalagi, dalam urusan kedinasan yang bersifat resmi, surat menyurat masih sangat dibutuhkan. Selain sebagai sarana komunikasi, surat juga berfungsi sebagai dokumen, arsip, atau bukti yang dibutuhkan untuk berbagai keperluan.

Surat dapat memberikan informasi sesuai dengan sumbernya. Surat mempunyai peran dalam setiap kegiatan untuk pengumpulan bahan-bahan keterangan, baik tertulis, terekam, tercetak, maupun tergambar. Surat adalah suatu media komunikasi yang berisi pernyataan tertulis yang berisi data atau informasi yang ingin disampaikan atau ditanyakan kepada si penerima surat (Nuraida, 2014: 61). Secara umun surat berfungsi sebagaimana tercermin dalam rumusan pengertiannya yaitu sebagai alat komunikasi tertulis untuk menyampaikan pesan atau informasi. Kaitannya dengan kegiatan pengabdian ini, maka surat yang dibahas yaitu surat dinas yang dipergunakan untuk kepentingan penyampaian pesan atau informasi di kantor kecamatan.

Kantor kecamatan sebagai salah satu kantor pemerintah yang melayani kepentingan umum tidak lepas dari kegiatan surat menyurat. Surat dapat memperlancar penyampaian informasi kepada pihak-pihak terkait. Surat mempunyai fungsi sebagai alat komunikasi, alat bukti tertulis, alat bukti historis, alat pengingat, duta organisasi, dan pedoman kerja. (Santosa dan Muhammad Zaruki, 2016: 134). Setiap kegiatan kecamatan selalu membutuhkan surat sebagai alat komunikasi untuk mencapai koordinasi kerja yang harmonis. Surat dapat memberikan informasi sesuai dengan sumbernya. Jenis surat yang digunakan dalam proses komunikasi tulis di kantor kecamatan ialah surat resmi atau surat dinas.

Surat resmi atau surat dinas merupakan surat yang dipergunakan untuk kepentingan yang bersifat resmi, baik yang ditulis perseorangan, instansi, lembaga maupun organisasi (Supriyana,dkk. 2015:7). Hal ini sejalan dengan yang diungkapkan oleh Rohmadi, dkk (2014:114) surat resmi atau surat dinas ialah surat yang digunakan dan dikirim oleh instansi atau masyarakat yang sifatnya resmi. Penulisan surat dinas merupakan salah satu kegiatan dalam administrasi yang dapat membantu kelancaran aktivitas bidang administrasi. Oleh karena itu, penulisan surat dinas sangat penting untuk mendukung proses kerja administrasi. Penulisan surat dinas sangat diperlukan di dalam sebuah lembaga sebagai sumber data atau informasi yang bermanfaat untuk kemajuan lembaga tersebut. Surat sebagai sarana komunikasi tertulis yang dapat menunjang tercapainya tujuan lembaga.

Surat yang baik ialah surat yang isinya mampu dipahami oleh penerima surat. Oleh karena itu, penulisan surat harus memenuhi syarat-syarat sebagaimana diungkapkan oleh Nurjamal, dkk (2017:121) ialah benar, jelas, lengkap, baik, bersih, rapi, tertib, dan sopan. Hal ini sejalan dengan yang diungkapkan oleh Soedjito \& Solichin TW (2014: 2) bahwa surat harus disusun dengan teknik penyusunan surat yang benar, isinya harus ringkas dan eksplisit dan menggunakan bahasa baku sesuai kaidah bahasa Indonesia. Berdasarkan observasi yang telah dilakukan, penulisan surat dinas di 
Kantor Kecamatan Gunungtanjung Kabupaten Tasikmalaya, belum memenuhi kriteria kaidah baku penulisan surat dinas. Hal ini disebabkan oleh faktor-faktor yang mempengaruhi penulisan surat dinas belum diperhatikan dengan serius. Setelah dilakukan analisis lebih lanjut, ternyata para pegawai kantor kecamatan masih menggunakan format lama dalam penulisan surat dinas. Para pegawai kantor kecamatan hanya meneruskan menulis surat dan menggantinya dengan hal-hal yang berhubungan dengan kegiatan atau informasi pada saat itu tanpa memperhatikan tata cara penulisan surat dinas yang baku.

Berdasarkan kenyataan di atas, maka pengabdi tergerak untuk melakukan perbaikan penulisan surat dinas oleh pegawai kantor kecamatan melalui pelatihan penulisan surat dinas. Pelatihan merupakan suatu proses yang dilakukan secara sistematis guna melakukan perubahan tingkah laku pegawai untuk mencapai tujuan organisasi (Rivai, 2005:225). Pelatihan yang dilaksanakan bertujuan untuk membantu para pegawai kantor kecamatan untuk memperoleh keahlian dan kemampuan dalam melaksanakan pekerjaanya..

\section{METODE PELAKSANAAN}

Menulis surat dinas memerlukan pengetahuan dan pemahaman mengenai tata cara penulisannya. Para pegawai kantor kecamatan harus dapat menulis surat dinas secara cermat, cepat dan menghasilkan informasi yang tepat agar kantor dapat memberikan pelayanan yang efektif. Kegiatan pelatihan penulisan surat dinas dilakukan unuk memberikan pemahaman tentang mekanisme penulisan surat dinas dan memotivasi para pegawai kantor kecamatan agar dapat menulis surat dinas secara tepat.

Pelaksanaan pengabdian dilakukan melalui tiga tahapan. Tahap yang pertama merupakan tahap persiapan. Pada tahap ini pengabdi melakukan survey pendahuluan untuk melihat kondisi di lapangan mengenai surat dinas yang telah dihasilkan oleh pegawai Kantor Kecamatan Gunungtanjung. Dalam tahap ini pengabdi menganalisis surat-surat yang ada di Kantor Kecamatan Gunungtanjung lalu mencari tahu permasalahan-permasalahan yang dihadapi oleh pegawai kantor kecamatan dalam menulis surat dinas. Tahap selanjutnya merupakan tahapan pelaksanaan kegiatan pengabdian. Dalam tahap ini pengabdi melakukan kegiatan dalam bentuk pelatihan penulisan surat dinas. Tahap yang terakhir adalah tahap evaluasi. Pada tahap ini dilakukan evaluasi atas hasil yang telah dicapai oleh peserta pelatihan. Masukan dan perbaikan lebih lanjut dapat dilakukan pada tahap ini.

Evaluasi diberikan dengan mengumpulkan data yang diperoleh dari kegiatan pelatihan penulisan surat dinas. Data diambil dengan menyimpulkan pemahaman para pegawai kantor kecamatan mengenai surat dinas ketika diberikan contoh surat dinas yang disampaikan dengan metode ceramah dan dilanjutkan dengan tanya jawab/diskusi, serta dari hasil penulisan surat dinas yang dihasilkan para pegawai kecamatan sebagai hasil dari pelatihan.

Pelaksanaan kegiatan Pengabdian Pada Masyarakat ini dikemas dengan menggunakan pendekatan workshop. Permasalahan bahwa para pegawai kantor 
Kecamatan Gunungtanjung Kabupaten Tasikmalaya masih kurang memahami penulisan surat dinas, diselesaikan menggunakan pendekatan persuasif-edukatif, yaitu dimaksudkan untuk memberikan pengetahuan, pemahaman, dan keterampilan dalam menulis surat dinas. Metode ceramah dilakukan dengan teknik presentasi materi surat dinas dilanjutkan dengan diskusi, sedangkan masalah kemampuan menulis surat dinas bagi para pegawai kantor kecamatan diselesaikan dengan memberikan pelatihan penulisan.

Adapun langkah-langkah dalam pelaksanaan kegiatan pengabdian ini adalah sebagai berikut.

1. Peserta pelatihan diberikan materi mengenai surat dinas.

2. Peserta diberikan kesempatan untuk mendiskusikan materi yang telah diberikan. Kesempatan tanya jawab diberikan untuk memperjelas hal-hal yang masih menjadi keraguan.

3. Peserta berlatih untuk menulis surat dinas.

4. Peserta diberikan bimbingan cara penulisan surat dinas.

5. Peserta yang belum mampu menulis surat dinas secara tepat, diberikan masukan dan perbaikan lebih lanjut.

Sasaran dari kegiatan pengabdian masyarakat ini adalah para pegawai Kantor Kecamatan Gunungtanjung Kabupaten Tasikmalaya sebanyak 30 orang.

\section{HASIL DAN PEMBAHASAN}

Kegiatan peningkatan pengetahuan dan keterampilan para pegawai kantor kecamatan dalam menghasilkan surat dinas melalui pelatihan penulisan surat dinas dilaksanakan di Ruang Aula Kantor Kecamatan Gunungtanjung Kabupaten Tasikmalaya. Kegiatan pelatihan berjalan dengan lancar dan dihadiri oleh 30 peserta. Peserta pelatihan terlihat antusias dengan materi pelatihan yang diberikan. Hal ini terlihat dari awal hingga akhir acara, semua peserta mengikuti kegiatan dengan baik.

Materi mengenai konsep penulisan surat dinas diberikan pada hari pertama pelatihan. Hal ini dilakukan dengan tujuan untuk memberikan pengetahuan mengenai pengertian, jenis, fungsi, format surat dan kesalahan-kesalahan yang sering ditemukan dalam surat dinas. Pada hari kedua peserta pengabdian melakukan workshop penulisan surat dinas dan melakukan kegiatan menulis surat dinas. Hasil karya para pegawai kantor kecamatan dikumpulkan, dianalisis, selanjutnya diberi masukan dan diperbaiki lagi. Selama proses penulisan dilakukan tanya jawab dan diskusi antara peserta dan pengabdi untuk meningkatkan pemahaman sehingga akan memperoleh hasil yang diinginkan.

Berdasarkan hasil kegiatan penulisan surat dinas, dapat diidentifikasi mengenai tingkat pemahaman peserta pengabdian adalah bahwa $95 \%$ peserta pengabdian memahami konsep penulisan surat dinas secara baik dan benar. Pemahaman mengenai penulisan surat dinas dapat tergambar melalui peningkatan penguasaan terhadap informasi dan ilmu pengetahuan serta para peserta mampu menerapkan ilmu 
pengetahuann tentang perbaikan mutu melalui penggunaan cara penulisan surat dinas yang baik dan benar.

Kegiatan pengabdian pelatihan penulisan surat dinas bagi para pegawai Kantor Kecamatan Gunungtanjung Kabupaten Tasikmalaya yang dilaksanakan dengan tujuan untuk meningkatkan profesionalitas para pegawai dapat berjalan dengan lancar. Pelatihan penulisan surat dinas memang nyata-nyata dibutuhkan bagi para pegawai Kantor Kecamatan Gunungtanjung Kabupaten Tasikmalaya. Dalam proses pelatihan, kebanyakan peserta mengeluhkan kurangnya pengetahuan dan pemahaman akan tata cara penulisan surat dinas untuk meningkatkan profesionalitas mereka sebagai pegawai kecamatan. Hingga dengan berakhirnya pelatihan, pada akhirnya para pegawai kecamatan menyadari sepenuhnya bahwa surat dinas penting bagi mereka sebagai bentuk perwujudan pertanggungjawaban.

Kegiatan pelatihan ini dapat berjalan sesuai dengan yang diharapkan oleh pengabdi. Hal ini disebabkan adanya faktor yang mendukung berjalannya kegiatan pengabdian. Hal-hal yang mendukung berjalannya kegiatan pengabdian ini dapat diidentifikasi diantaranya antusisme para peserta pelatihan. Faktor yang mendukung kegiatan adalah antusiasme peserta untuk memahami konsep penulisan surat dinas. Antusisme dibuktikan dengan banyaknya pertanyaan yang muncul ketika pelaksanaan diskusi kelompok, pengerjaan tugas yaitu penulisan surat dinas serta tidak adanya peserta yang membolos selama pelatihan..

\section{SIMPULAN}

Simpulan dari kegiatan pelatihan penulisan surat dinas yang telah dilaksanakan sebagai berikut.

1. Pelatihan ini telah mampu menumbuhkan minat dan rasa percaya diri di kalangan para pegawai dalam menulis surat dinas. Hal ini tampak dari keantusiasan dan ketekunan peserta dalam mengikuti pelatihan sampai akhir kegiatan. Selain itu, antusiasme peserta pelatihan dibuktikan dari terjadinya proses interaksi aktif antara penyaji dan peserta pada saat pelaksanaan pelatihan. Ada keterlibatan mentalpsikologis dalam upaya peserta untuk memahami isi sajian pelatihan.

2. Kualitas surat dinas yang telah dihasilkan oleh para pegawai Kantor Kecamatan Gunungtanjung Kabupaten Tasikmalaya mengalami peningkatan sebagaimana uraian berikut. 20 surat dinas dengan kategori sangat baik, 7 surat dinas dengan kategori baik, dan 3 surat dinas tergolong katerori cukup (skor $<70$ ).

\section{SARAN}

Setelah melaksanakan kegiatan pengabdian yang berbentuk pelatihan penulisan surat dinas di Kantor Kecamatan Gunungtanjung Kabupaten Tasikmalaya, pengabdi merekomendasikan hal-hal berikut yang diambil setelah menyimpulkan hasil kegiatan.

1. Perlu pembinaan lebih lanjut, agar para pegawai dapat mengoptimalkan kemampuan menulis surat dinas. 
2. Pelaksanaan pelatihan surat dinas dapat diperluas jangkauannya ke kantor kecamatan lainnya di Kabupaten Tasikmalaya.

3. Acara pelatihan dapat dilaksanakan dalam durasi lebih lama, sehingga para pegawai kecamatan dapat lebih leluasa pada kegiatan pelatihan penulisan surat dinas.

4. Kegiatan yang dilaksanakan oleh Dosen Program Studi Pendidikan Bahasa dan Sastra Indonesia FKIP Unigal dengan sasaran para pegawai kantor kecamatan diharapkan dapat dilanjutkan dengan kegiatan-kegiatan lainnya yang dibutuhkan oleh para pegawai kecamatan.

\section{UCAPAN TERIMA KASIH}

Penulis mengucapkan terima kasih kepada Program Studi Bahasa dan Sastra Indonesia, Fakultas Keguruan dan Ilmu Pendidikan (FKIP) Universitas Galuh serta Lembaga Penelitian dan Pengabdian Masyarakat (LPPM) Universitas Galuh yang telah memberikan dukungan dan dana kegiatan pengabdian kepada masyarakat.

\section{DAFTAR PUSTAKA}

Nuraida, Ida. (2014). Manajemen Administrasi Perkantoran. Yogyakarta:PT Kanisius. Nurjamal, Daeng dkk. (2017). Terampil Berbahasa.Bandung: Alfabeta.

Rivai , Veithzal. (2005). Manajemen Sumber Daya Manusia Untuk Perusahaan dari Teori ke Praktik. Jakarta: PT. Rajagrafindo Persada.

Rohmadi,dkk. (2014). Belajar Bahasa Indonesia. Surakarta: Cakrawala Media.

Santosa, Puji dan Muhammad Jaruki. (2016). Mahir Berbahasa Indonesia. Bandung: PT Remaja Rosda Karya.

Soedjito \& Solichin TW. (2016). Surat Menyurat Resmi Bahasa Indonesia. Bandung: PT Remaja Rosdakarya.

Supriyana, Asep dkk.(2015). Pelatihan Penggunaan Ejaan Yang Disempurnakan dan Kalimat Efektif pada Penulisan Surat Resmi bagi Guru Sekolah Dasar di Jakarta Timur. Jurnal Sarwahita. Vol 12 No 1 : hal 1-12. 